\title{
ANALISA BANJIR D.I SENGKALING KANAN AKIBAT ALIH FUNGSI SALURAN IRIGASI MENJADI SALURAN DRAINASE
}

\author{
Anandini Fatma Arfiyanti ${ }^{1}$, Suhardjono ${ }^{2}$, Lily Montarcih L. $^{2}$ \\ ${ }^{1}$ Mahasiswa Program Magister Teknik Jurusan Pengairan Universitas Brawijaya \\ ${ }^{2}$ Dosen Teknik Pengairan Fakultas Teknik Universitas Brawijaya \\ e-mail: anandinifatma@gmail.com
}

\begin{abstract}
ABSTRAK Perubahan secara cepat pada tata guna lahan menuntut adanya usaha penanganan sistem pembawa air yang tepat pada lahan. Sebab dengan adanya perubahan tata guna lahan tersebut, dapat berakibat terjadinya perubahan fungsi saluran irigasi menjadi saluran drainase. Studi ini dipusatkan pada DTA Intake Sengkaling Kanan, karena daerah ini mempunyai banyak titik yang mempunyai permasalahan genangan di saat musim hujan datang setiap tahunnya. Sebagai contoh pada saat musim hujan tinggi tahun 2012 genangan yang terjadi mencapai 1,5 meter. Hal ini menyebabkan terganggunya aktifitas penduduk di lokasi tersebut karena daerah ini merupakan pusat pertokoan, pemukiman, dan pemerintahan/ perkantoran. Dari permasalahan tersebut direncanakan 2 pelimpah samping 1 diletakkan pada Sub DAS 3 mengalirkan debit sejumlah $5,47 \mathrm{~m}^{3} / \mathrm{dt}$ dan pelimpah samping 2 diletakkan pada Sub DAS 8 mengalirkan debit sejumlah $5,58 \mathrm{~m}^{3} / \mathrm{dt}$.
\end{abstract}

Kata Kunci: Banjir, Drainase, Irigasi, Saluran, Tata Guna Lahan

\begin{abstract}
Rapid changes in land-use business management system requires proper water carrier on the land. Because with the change in the land use, may result in changes in the function of the irrigation channel into the drainage channel. This study focused on DTA Intake Sengkaling Right, because this area has a lot of points that have problems inundation during the rainy season comes every year. For example during the rainy season high inundation occurred in 2012 reached 1.5 meters. This causes disruption of activity of the population in these locations because this area is a shopping center, residential, and government / offices. From the problems of planned 21 put on the spillway side subzone 3 drain discharge amount of $5.47 \mathrm{~m}^{3} / \mathrm{s}$ and 2 is placed on the side spillway subzone 8 drain discharge amount of $5.58 \mathrm{~m}^{3} / \mathrm{sec}$.
\end{abstract}

Keywords: Flood, Drainage, Irrigation, Channels, Land Use

Perubahan secara cepat pada tata guna lahan menuntut adanya usaha penanganan sistem pembawa air yang tepat pada lahan.

Sebab dengan adanya perubahan tata guna lahan tersebut, dapat berakibat terjadinya perubahan fungsi saluran irigasi menjadi saluran drainase.

Sebagai Kota yang berkembang, Kota Malang merupakan salah satu daerah tingkat II yang menjadi tujuan bagi banyak orang untuk bermukim dalam pemenuhan kebutuhan hidupnya.

Akibatnya Kota Malang banyak mengalami perubahan. Tata guna lahan yang dulunya berupa daerah persawahan banyak beralih fungsi menjadi daerah perkantoran maupun pemukiman. Seiring dengan terjadinya perubahan tersebut tentunya juga akan membawa dampak negatif diantaranya berupa genangan yang banyak terjadi di beberapa kawasan di wilayah Kota Malang.

Studi ini dipusatkan pada DTA Intake

Sengkaling Kanan, karena daerah ini mempunyai banyak titik yang mempunyai permasalahan genangan di saat musim hujan datang setiap tahunnya.

Sebagai contoh pada saat musim hujan tinggi tahun 2012 genangan yang terjadi mencapai 1,5 meter. Hal ini menyebabkan terganggunya aktifitas penduduk di lokasi 
tersebut karena daerah ini merupakan pusat pertokoan, pemukiman, dan pemerintahan/ perkantoran.

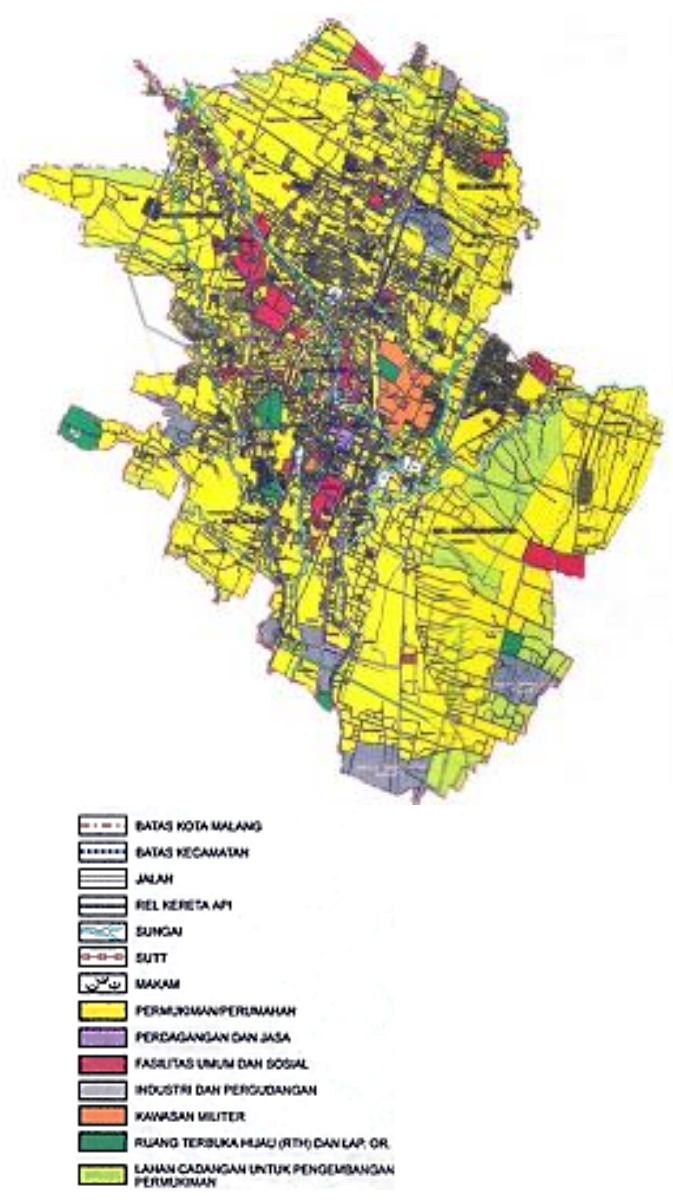

\section{Gambar 1. Peta RTRW Kota Malang}

\section{Identifikasi Masalah}

Dari beberapa masalah di atas dapat diambil beberapa identifikasi masalah dari studi ini antara lain : Genangan yang terjadi di sepanjang daerah tangkapan air kemungkinan disebabkan oleh perubahan tata guna lahan dari daerah persawahan menjadi daerah permukiman/perkantoran. Juga akibat adanya perubahan fungsi saluran irigasi yang sebelumnya membawa debit irigasi menjadi penambahan debit banjir saat musim hujan datang. Sistem saluran drainase dan irigasi yang ada di wilayah tersebut tidak tertata dengan baik. Oleh sebab itu diperlukan analisa mengenai debit banjir yang terjadi pada daerah tangkapan air tersebut, untuk dapat memberikan solusi yang bisa menyelesaikan masalah genangan pada daerah tersebut.

\section{Tujuan dan Manfaat}

Tujuan penelitian yaitu untuk mengetahui sejauh mana perubahan fungsi saluran irigasi menjadi saluran drainase pada DTA D.I Sengkaling Kanan tersebut, mengetahui besar debit limpasan yang diakibatkan perubahan tata guna lahan pada DTA D.I Sengkaling Kanan tersebut dan mencari alternatif penanggulangan genangan yang sesuai dengan kondisi setempat

Manfaat Hasil kajian ini adalah untuk mengetahui alternatif penanggulangan yang sesuai dengan kondisi wilayah setempat dan memberikan masukan terhadap instansi terkait supaya genangan yang ada dapat teratasi, sehingga tidak mengganggu aktifitas masyarakat dan pemerintah setempat.

\section{TINJAUAN PUSTAKA}

\section{Hidrologi dan Ekosistem Daerah Sungai}

Daerah aliran sungai dapat dianggap sebagai suatu ekosistem, karena ekosistem adalah suatu sistem ekologi yang terdiri atas komponen-komponen yang saling berintegrasi sehingga membentuk suatu kesatuan. Ekosistem terdiri atas komponen biotis dan abiotis yang saling berinteraksi membentuk satu kesatuan yang teratur. Aktivitas suatu komponen ekosistem selalu memberi pengaruh pada komponen ekosistem yang lain. Manusia adalah salah satu komponen yang penting. Sebagai komponen yang dinamis, manusia dalam menjalankan aktivitasnya seringkali mengakibatkan dampak pada salah satu komponen lingkungan, dan dengan demikian akan mempengaruhi ekosistem secara keseluruhan. (Chay Asdak, 2002).

\section{Analisa Hidrologi}

Proses analisa hidrologi pada dasarnya merupakan proses pengolahan data curah hujan, data luas dan bentuk daerah pengaliran (catchment area), data kemiringan lahan atau beda tinggi, dan data tata guna lahan yang kesemuanya memiliki arahan untuk mengetahui besarnya curah hujan maksimum, koefisien pengaliran, waktu konsentrasi, intensitas curah hujan, dan debit banjir rencana.

\section{Uji Homogenitas Data}

Ada beberapa macam metode uji homogenitas data dengan berbagai syarat kondisi dalam penggunaannya, yaitu : 


\section{Metode Parametrik}

Metode parametrik menganggap populasinya mempunyai atau mengikuti distribusi tertentu. Dalam metode parametrik diperlukan parameter khusus, misal : nilai rata-rata, deviasi standar, variansi dari populasi yang diamati.

Ada beberapa uji homogenitas yang bersifat parametrik, diantaranya :

a. Uji T : Umumnya digunakan untuk menguji sampel data ukuran kecil $(\mathrm{N}<30)$.

b. Uji F : Uji F bisa digunakan untuk sampel data besar $(\mathrm{N} \geq 30)$ atau untuk sampel data kecil $(\mathrm{N}<30)$. Pada kenyataannya sebelum menguji rata-rata sampel salah satu hal yang harus diuji adalah kehomogenitasan nilai varian dari sampel data.

\section{Metode Non Parametrik}

Metode non parametrik tidak memerlukan parameter-parameter di dalam sampel data.

Salah satu contoh uji homogenitas yang bersifat non parametrik, yaitu :

a. Uji Z : Uji Z dapat digunakan untuk menguji apakah dua kelompok data yang tidak berpasangan berasal dari populasi yang sama atau tidak. Walaupun demikian apabila anggapan-anggapan yang diperlukan dalam uji parametrik terpenuhi, datanya cukup banyak, dan hasil pengukuran lebih teliti maka lebih baik menggunakan uji parametrik (Suwarno, 1995)

b. Uji F (Fisher Test) : Uji analisis pada dasarnya adalah menghitung nilai $\mathrm{F}$ score, dan kemudian lalu membandingkan dengan $\mathrm{F}$ tabel. Yang mana nilai yang diuji adalah ketidak tergantungan (independence) atau keseragaman (homogenitas).Uji pada analisa variansi dapat bersifat satu atau dua arah.

\section{Analisa Frekuensi}

Tabel 1. Parameter Statistik untuk menentukan Jenis distribusi

\begin{tabular}{cl}
\hline No Distribusi & Persyaratan \\
\hline 1 Normal & $\left(\mathrm{x}_{\text {rerata }} \pm \mathrm{s}\right)=68,27 \%$ \\
& $\left(\mathrm{x}_{\text {rerata }} \pm 2 \mathrm{~s}\right)=95,44 \%$ \\
& $\mathrm{C}_{\mathrm{s}} \approx 0$ \\
& $\mathrm{C}_{\mathrm{k}} \approx 3$ \\
\hline 2 Log Normal & $\mathrm{C}_{\mathrm{s}}=\mathrm{C}_{\mathrm{v}}{ }^{3}+3 \mathrm{C}_{\mathrm{v}}$ \\
& $\mathrm{C}_{\mathrm{k}}=\mathrm{C}_{\mathrm{v}}{ }^{8}+6 \mathrm{C}_{\mathrm{v}}{ }^{6}+15 \mathrm{C}_{\mathrm{v}}{ }^{4}+16 \mathrm{C}_{\mathrm{v}}{ }^{2}+3$ \\
\hline 3 Gumbel & $\mathrm{C}_{\mathrm{s}}=1,14$ \\
& $\mathrm{C}_{\mathrm{k}}=5,4$ \\
\hline 4 Log Pearson & Selain dari nilai di atas \\
\hline Sumber: Triatmodjo (2010)
\end{tabular}

Dalam analisa hirologi selanjutnya, diperlukan besaran curah hujan rencana yang terjadi di daerah tersebut. Curah hujan rencana adalah berupa besaran jumlah hujan yang terjadi selama satu hari dalam satuan milimeter, dalam berbagai kala ulang yang telah direncanakan.

Persamaan untuk perhitungan koefisien kepencengan $(\mathrm{Cs})$ dan koefisien puncak $(\mathrm{Ck})$ :

$$
\begin{aligned}
& C s=\frac{n \sum(x-\bar{x})^{3}}{(n-1)(n-2) S^{3}} . \\
& C k=\frac{n^{2} \sum(x-\bar{x})^{4}}{(n-1)(n-2)(n-3) S^{4}} .
\end{aligned}
$$

$$
\begin{aligned}
& \text { Dengan: } \\
& \mathrm{Cs}=\text { skewness/ kepencengan } \\
& \mathrm{Ck}=\text { kurtosis } / \text { koefisien puncak } \\
& \mathrm{S}=\text { simpangan baku } \\
& \mathrm{n}=\text { jumlah data }
\end{aligned}
$$

\section{Distribusi Normal}

Distribusi normal adalah simetris terhadap sumbu vertikal dan berbentuk lonceng yang juga disebut distribusi Gauss. Distribusi normal mempunyai dua parameter yaitu rerata $\mu$ dan deviasi standar $\sigma$ dari populasi. Dalam praktek, nilai rerata $\mathrm{x}$ dan deviasi standar s diturunkan dari data sampel untuk menggantikan $\mu$ dan $\sigma$. Fungsi distribusi normal mempunyai bentuk:

$$
\begin{aligned}
& \begin{array}{l}
p(X)=\frac{1}{\sigma \sqrt{2 \pi}} e^{-(X-\mu)^{2} /\left(2 \sigma^{2}\right)} \\
\quad \text { dengan }
\end{array} \\
& \mathrm{X}=\text { nilai pada periode ulang tertentu } \\
& \mathrm{X}^{2}=\text { nilai rerata } \\
& \mathrm{K}=\text { faktor frekuensi untuk sebaran } \\
& \quad \text { Normal (didapat dari table) } \\
& \sigma=\text { standart deviasi }
\end{aligned}
$$

\section{Distribusi Gumbel}

Distribusi gumbel banyak digunakan untuk analisis data maksimum, seperti untuk analisis frekuensi banjir. Persamaan yang digunakan adalah:

$$
\begin{aligned}
& x=\bar{x}+\frac{y T-y n}{S_{n}} \sigma \\
& \text { dengan } \\
& \mathrm{X}=\text { nilai ekstrim } \\
& \quad=\text { nilai rata-rata } \\
& \overline{\mathrm{Y}}_{\mathrm{t}}=\text { reduced variate, merupakan fungsi } \\
& \text { probabilitas atau dengan rumus: } \\
& \quad y_{T}=-\ln \left[\ln \left(\frac{T r}{T r-1}\right)\right] \\
& \mathrm{Y}_{\mathrm{n}}=\text { reduced variate mean (didapat dari } \\
& \quad \text { tabel) }
\end{aligned}
$$




$$
\begin{gathered}
S_{\mathrm{n}}=\begin{array}{c}
\text { standar deviasi variat (didapat dari } \\
\text { tabel) }
\end{array} \\
\sigma=\text { simpangan baku (deviasi standar) }
\end{gathered}
$$

\section{Uji Kesesuaian Distribusi Frekuensi}

Uji kesesuaian distribusi dimaksudkan untuk mengetahui kebenaran hipotesa, dalam hal ini hipotesa distribusi frekuensi data hujan. Sebelum dilakukan perhitungan dan analisa, keandalan data perlu dipastikan terlebih dahulu. Pengujian dilakukan untuk memastikan ketepatannya agar hasil perhitungan tersebut dapat dipergunakan untuk proses perhitungan selanjutnya.

\section{Uji Smirnov-Kolmogorov}

Uji kesesuaian Smirnov-Kolmogorov ini digunakan untuk menguji simpangan secara mendatar. Uji ini dilakukan dengan tahapan sebagai berikut:

1. Data curah hujan diurutkan dari kecil ke besar

2. Menghitung besarnya harga probabilitas dengan persamaan Weibull sebagai berikut :

$$
P(x)=\frac{m}{(n+1)} x 100 \%
$$

$$
\text { dimana : }
$$

$$
\begin{array}{ll}
P= & \text { Probabilitas (\%) } \\
m= & \text { Nomor urut data } \\
n= & \text { Jumlah data }
\end{array}
$$

\section{Intensitas Hujan}

Sebelum melakukan perhitungan debit banjir rancangan (Design Flood) diperlukan perhitungan intensitas hujan. Analisis intensitas curah hujan ini dapat diproses dari data curah hujan yang telah terjadi di masa lampau. Intensitas hujan dapat diperoleh dari data hujan otomatis sehingga diperoleh hujan dengan durasi singkat. Apabila data yang tersedia adalah data hujan harian Mononobe (Suyono dan Takeda, 1983) memberikan persamaan sebagai berikut:

$$
I_{T}=\frac{R_{24}}{t} \cdot\left(\frac{t}{T}\right)^{\frac{2}{3}}
$$

dengan:

$\mathrm{I}_{\mathrm{T}} \quad=$ intensitas curah hujan dalam $\mathrm{T}$ jam $(\mathrm{mm} / \mathrm{jam})$

$\mathrm{R}_{24}=$ curah hujan harian ( $\mathrm{mm}$ )

$\mathrm{T} \quad=$ waktu hujan dari awal sampai jam ke t (jam) $\mathrm{t}=$ lama curah hujan (jam)

\section{Koefisien Pengaliran}

Koefisien limpasan (C) adalah perbandingan antara jumlah air yang mengalir (melimpas) di pemukaan dari suatu kawasan akibat turunnya hujan dengan jumlah air hujan yang turun di kawasan tersebut (Suhardjono, 2015).

Besarnya koefisien limpasan (run off) ini dipengaruhi oleh banyak faktor, antara lain yaitu:

a. Kemiringan daerah aliran dan kemiringan DPSal sungai, semakin besar kemiringan tanah, semakin cepat aliran limpasan, akibatnya semakin sedikit air yang meresap.

b. Jenis tanah yang berbeda menjadikan daya resap tanah yang berbeda, misalnya (a) tanah biasa atau pasir, (b) jalan aspal atau tanah

c. Kebasahan tanah, pada permulaan musim hujan angka pengaliran lebih kecil, karena lebih banyak air hujan yang tertahan, daripada di akhir musim hujan, karena pada saat itu tanah telah jenuh air.

d. Tata guna lahan, berbedanya macam pemakaian lahan membawa perbedaan kemapuan kawasan dalam menahan air, misalnya kawasan perumahan lebih banyak melimpaskan air daripada daerah pertamanan.

Apabila suatu kawasan terdiri dari berbagai macam penggunaan lahan dengan koefisien limpasan permukaan yang berbeda-beda, maka koefisien limpasan yang dipakai merupakan $\mathrm{C}$ gabungan yang dihitung dengan rumus (Suhardjono, 2015):

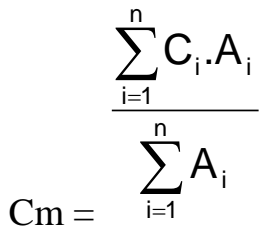

dengan :

$\mathrm{Cm} \quad=\mathrm{Cgab}=$ Koefisien limpasan gabungan.

$\mathrm{Ai}=$ luas masing-masing tata guna lahan

$\mathrm{Ci}=$ Koefisien limpasan setiap tata guna lahan.

Besaran nilai masing-masing koefisien limpasan (C) yang umum dipakai untuk 
rancangan drainase pada perkotaan adalah sebagaimana yang tertera pada tabel dibawah ini:

Tabel 2. Besaran koefisien limpasan (C)

\begin{tabular}{|l|l|}
\hline Tata guna lahan & $\begin{array}{l}\text { Koefisien } \\
\text { limpasan (C) }\end{array}$ \\
\hline Bisnis & $0,70-0,95$ \\
Kawasan Kota & $0,50-0,70$ \\
\hline Kawasan Pinggiran & $0,30-0,50$ \\
\hline Kawasan Perumahan & $0,40-0,60$ \\
Kawasan keluarga tunggal & $0,60-0,75$ \\
\hline Multi satuan, terpisah & $0,25-0,40$ \\
\hline Multi satuan, berdempetan (rapat) & $0,50-0,70$ \\
\hline Kawasan pemukiman pinggiran kota & \\
\hline Kawasan rumah tinggal berupa rumah susun (apartment) & $0,5-0,90$ \\
\hline Perindustrian & $0,10-0,25$ \\
\hline Kawasan ringan-berat & $0,20-0,35$ \\
\hline Taman-taman dan kuburan & $0,20-0,40$ \\
\hline Lapangan bermain & $0,10-0,30$ \\
\hline Kawasan halaman kereta api & \\
\hline Kawasan yang belum dimanfaatkan & $0,70-0,95$ \\
\hline Jalan & $0,80-0,95$ \\
Beraspal & $0,70-0,85$ \\
\hline Beton & $0,70-0,85$ \\
\hline Batu bata/paving block/con block & $0,70-0,95$ \\
\hline Jalan raya dan trotoar & $0,05-0,10$ \\
\hline Atap & $0,05-0,10$ \\
\hline Halaman rumput, tanah berpasir & $0,05-0,10$ \\
\hline Tanah berpasir, datar (2\%) & \\
Tanah berpasir, rata-rata (2-7\%) & $0,13-0,17$ \\
Tanah berpasir, curam (>7\%) & $0,18-0,22$ \\
\hline Halaman rumput, tanah padat & $0,25-0,35$ \\
\hline Tanah padat, datar (2\%) & \\
Tanah padat, rata-rata (2-7\%) & \\
Tanah padat, curam (>7\%) & \\
\hline
\end{tabular}

Sumber : Panduan dan Petunjuk Praktis Pengelolaan Drainase Perkotaan, Departemen Pemukiman dan Prasarana Wilayah

\section{Waktu Konsentrasi (Tc)}

Adalah waktu yang diperlukan air untuk mengalir dari titik terjauh pada suatu DAS hingga titik pengamatan aliran (outlet)

\section{Pelimpah Samping}

Metode numeris didasarkan pada cara pemecahan masalah analitis yang diperkenalkan Marchi (KP. Penunjang, 1986)

Pelimpah samping dibuat di hulu daerah banjir adalah beda debit eksisting $\left(\mathrm{Q}_{1}\right)$ dan debit rencana $\left(\mathrm{Q}_{2}\right)$.

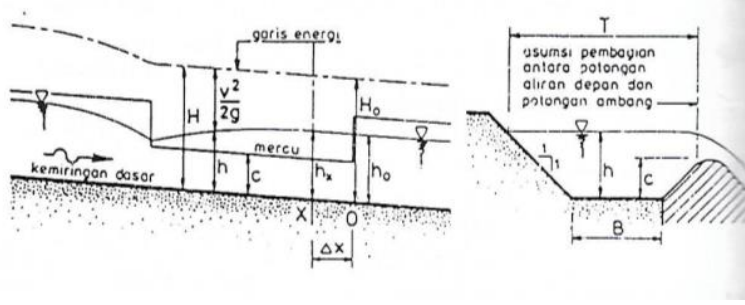

Gambar 2. Sketsa definisi bangunan pelimpah samping

\section{Pengolahan Data dengan Sistem Informasi Geografis (SIG)}

Perkembangan Digital Terrain Model (DTM) atau juga biasa disebut sebagai Digital Elevation Model (DEM) adalah salah satu metode pendekatan yang bisa dipakai untuk memodelkan relief permukaan bumi dalam bentuk 3 (tiga) dimensi. Model ini sesuai dalam menentukan luasan dan bentuk suatu Daerah Aliran Sungai (DAS). Perkembangan dari teknologi SIG dan DEM saat ini telah memungkinkan untuk membantu proses analisa suatu fenomena limpasan permukaan.
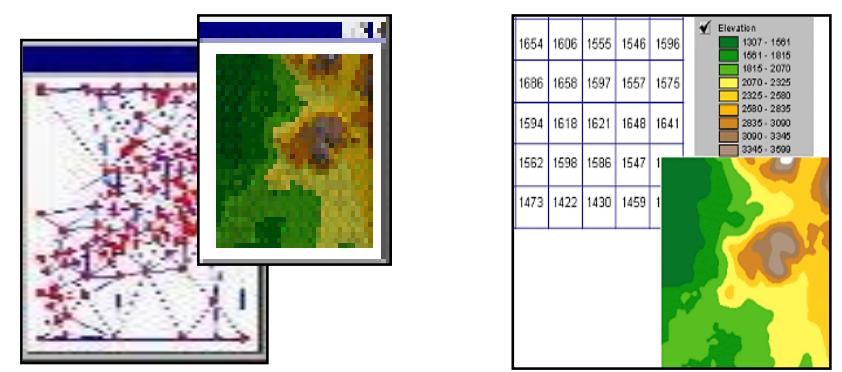

Gambar 3. Tipe model permukaan digital Sumber : (Prahasta, 2005)

\section{METODE PENELITIAN}

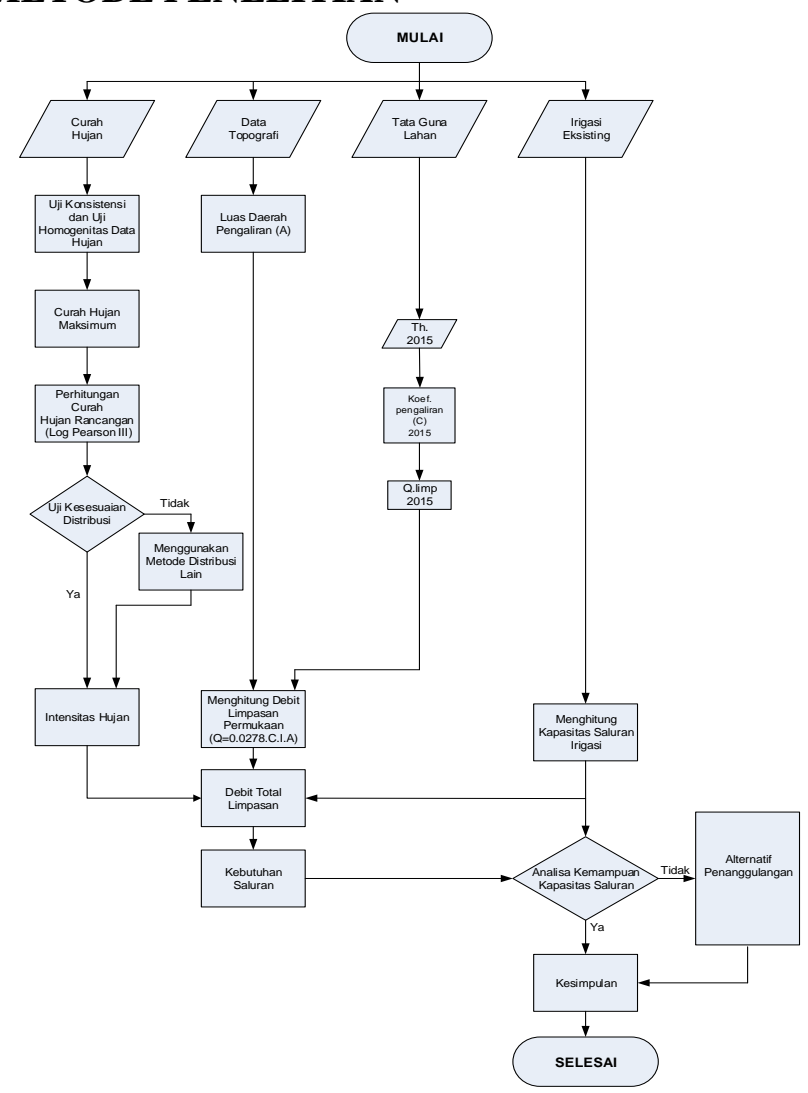

Gambar 4. Flowchart 


\section{HASIL PEMBAHASAN}

\section{Ketersediaan Data Hujan}

Pada analisa hidrologi diperlukan data hujan sebagai input. Pada studi ini digunakan data hujan Stasiun Hujan Jurusan Pengairan Universitas Brawijaya. Pada stasiun hujan tersebut tersedia data selama 17 tahun yaitu mulai 1997 sampai dengan 2013. Tabel 3. menampilkan data curah hujan harian maksimum dari stasiun tersebut:

Tabel 3. Curah hujan maksimum harian tahun 1997-2013

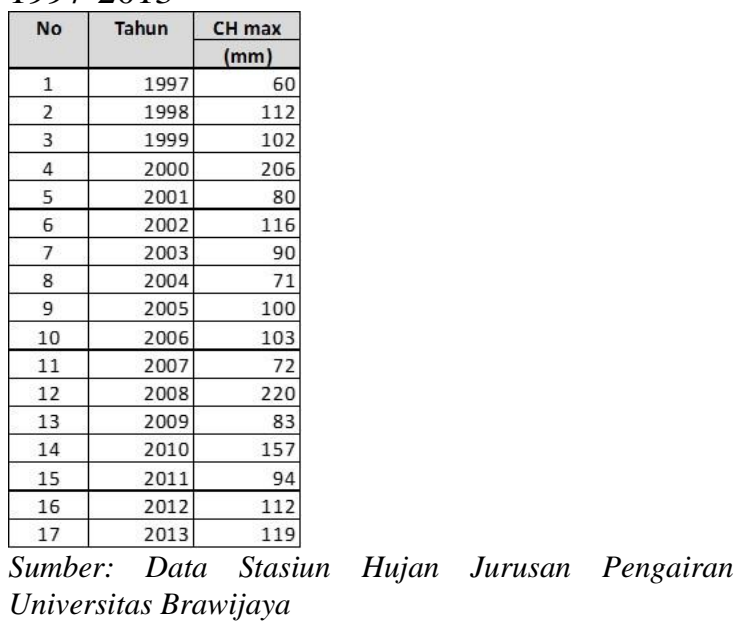

\section{Validasi Data Hujan}

Data curah hujan Stasiun Hujan Jurusan Pengairan Universitas Brawijaya disusun dalam bentuk deret berkala yaitu mulai tanggal 1 Januari sampai dengan 31 Desember setiap tahun.

\section{Uji Ketiadaan Trend}

Data yang diperlukan pada validasi data hujan metode Spearman adalah data hujan tahunan. Tabel 4 menampilkan hasil pengujian ketiadaan trend metode Spearman.

Tabel 4. Uji Ketiadaan Trend Metode Spearman

\begin{tabular}{|c|c|c|c|c|c|c|c|}
\hline \multirow{2}{*}{ No. } & \multirow{2}{*}{ Tahun } & \multirow{2}{*}{$\begin{array}{c}\text { Curah Hujan } \\
\operatorname{Max}(\mathrm{mm})\end{array}$} & \multicolumn{3}{|c|}{ Peringkat } & \multirow{2}{*}{$\mathrm{dt}$} & \multirow{2}{*}{$\mathrm{dt}^{2}$} \\
\hline & & & Tahun & $\mathrm{CH}$ & Rt & & \\
\hline 1 & 1997 & 60.25 & 2008 & 220.00 & 12 & 11 & 121 \\
\hline 2 & 1998 & 112.25 & 2000 & 206.00 & 4 & 2 & 4 \\
\hline 3 & 1999 & 101.75 & 2010 & 156.50 & 14 & 11 & 121 \\
\hline 4 & 2000 & 206.00 & 2013 & 119.00 & 17 & 13 & 169 \\
\hline 5 & 2001 & 80.00 & 2002 & 116.00 & 6 & 1 & 1 \\
\hline 6 & 2002 & 116.00 & 1998 & 112.25 & 2 & -4 & 16 \\
\hline 7 & 2003 & 90.00 & 2012 & 111.50 & 16 & 9 & 81 \\
\hline 8 & 2004 & 71.15 & 2006 & 102.50 & 10 & 2 & 4 \\
\hline 9 & 2005 & 100.40 & 1999 & 101.75 & 3 & -6 & 36 \\
\hline 10 & 2006 & 102.50 & 2005 & 100.40 & 9 & -1 & 1 \\
\hline 11 & 2007 & 71.50 & 2011 & 93.50 & 15 & 4 & 16 \\
\hline 12 & 2008 & 220.00 & 2003 & 90.00 & 7 & -5 & 25 \\
\hline 13 & 2009 & 83.00 & 2009 & 83.00 & 13 & 0 & 0 \\
\hline 14 & 2010 & 156.50 & 2001 & 80.00 & 5 & -9 & 81 \\
\hline 15 & 2011 & 93.50 & 2007 & 71.50 & 11 & -4 & 16 \\
\hline 16 & 2012 & 111.50 & 2004 & 71.15 & 8 & -8 & 64 \\
\hline 17 & 2013 & 119.00 & 1997 & 60.25 & 1 & -16 & 256 \\
\hline
\end{tabular}

Berdasarkan perhitungan dari tabel 4 maka dapat dihitung nilai koefisien korelasi Spearman sebagai berikut

$$
\begin{aligned}
\mathrm{KP} & =1-\frac{6 \sum_{i=3}^{n}(d t)^{2}}{n^{3}-n} \\
\mathrm{KP} & =1-\frac{6.072}{17^{3}-17} \\
& =-0.24
\end{aligned}
$$

Selanjutnya dari Persamaan

$$
\begin{aligned}
\mathrm{t} & =\mathrm{KP}\left[\frac{n-2}{1-K P^{2}}\right]^{1 / 2} \\
\mathrm{t} & =-0.24\left[\frac{17-2}{1-(-0.24)^{2}}\right]^{1 / 2} \\
& =-0.96
\end{aligned}
$$

Selanjutnya dilakukan pengujian dua sisi untuk derajat kepercayaan 5\% dan derajat kebebasan $\mathrm{dk}=\mathrm{n}-2=15$, berdasarkan tabel nilai kritis tc untuk distribusi- $\mathrm{t}$ uji dua sisi (dapat dilihat pada Lampiran). Maka diperoleh $\mathrm{t}_{0.975}=2.131$ dan $\mathrm{t}_{-0.975}=-2.131$. Dari perhitungan maka nilai $\mathrm{t}$ terletak $-2.131<-0.96<2.131$, oleh karena itu dapat disimpulkan bahwa data tersebut independen dan tidak menunjukkan trend.

\section{Uji Konsistensi}

digunakan Satu seri data hujan untuk satu stasiun tertentu, dimungkinkan sifatnya tidak konsisten. Oleh karena itu perlu dilakukan uji konsistensi. Pada studi ini digunakan metode RAPS. Berikut ini adalah pengujian RAPS untuk Stasiun Hujan Jurusan Pengairan Universitas Brawijaya.

Tabel 5. Uji Konsistensi Metode RAPS Stasiun Hujan Jurusan Pengairan Universitas Brawijaya

\begin{tabular}{|c|r|r|r|r|c|}
\hline No. & Tahun & $\begin{array}{c}\text { Curah Hujan } \\
\text { Max(mm) }\end{array}$ & \multicolumn{1}{|c|}{ Sk* $^{*}$} & Sk** $^{* *}$ & Sk** $^{*}$ \\
\hline 1 & 1997 & 60.25 & -51.24 & -1.154 & 1.154 \\
\hline 2 & 1998 & 112.25 & 0.76 & 0.017 & 0.017 \\
\hline 3 & 1999 & 101.75 & -9.74 & -0.219 & 0.219 \\
\hline 4 & 2000 & 206.00 & 94.51 & 2.128 & 2.128 \\
\hline 5 & 2001 & 80.00 & -31.49 & -0.709 & 0.709 \\
\hline 6 & 2002 & 116.00 & 4.51 & 0.102 & 0.102 \\
\hline 7 & 2003 & 90.00 & -21.49 & -0.484 & 0.484 \\
\hline 8 & 2004 & 71.15 & -40.34 & -0.908 & 0.908 \\
\hline 9 & 2005 & 100.40 & -11.09 & -0.250 & 0.250 \\
\hline 10 & 2006 & 102.50 & -8.99 & -0.202 & 0.202 \\
\hline 11 & 2007 & 71.50 & -39.99 & -0.901 & 0.901 \\
\hline 12 & 2008 & 220.00 & 108.51 & 2.444 & 2.444 \\
\hline 13 & 2009 & 83.00 & -28.49 & -0.642 & 0.642 \\
\hline 14 & 2010 & 156.50 & 45.01 & 1.014 & 1.014 \\
\hline 15 & 2011 & 93.50 & -17.99 & -0.405 & 0.405 \\
\hline 16 & 2012 & 111.50 & 0.01 & 0.000 & 0.000 \\
\hline 17 & 2013 & 119.00 & 7.51 & 0.169 & 0.169 \\
\hline
\end{tabular}

\section{Analisa Frekuensi}

Pada studi digunakan empat metode untuk melakukan analisa frekuensi. menampilkan kajian setiap metode. 
Tabel 6. Perhitungan Pemilihan Distribusi

\begin{tabular}{|c|c|r|r|r|}
\hline No & Tahun & \multicolumn{1}{|c|}{ CH } & \multicolumn{1}{c|}{${\text { (x-rrt })^{\mathbf{3}}}^{\prime}$} & \multicolumn{1}{c|}{$(\mathbf{x} \text {-xrt })^{4}$} \\
\hline 1 & 1997 & 60.25 & $-3,768.74$ & $58,649.14$ \\
\hline 2 & 1998 & 112.25 & $48,379.75$ & $1,762,861.23$ \\
\hline 3 & 1999 & 101.75 & $17,450.56$ & $452,632.72$ \\
\hline 4 & 2000 & 206.00 & $2,206,545.39$ & $287,265,731.34$ \\
\hline 5 & 2001 & 80.00 & 73.45 & 307.63 \\
\hline 6 & 2002 & 116.00 & $64,906.65$ & $2,608,468.37$ \\
\hline 7 & 2003 & 90.00 & $2,856.04$ & $40,521.43$ \\
\hline 8 & 2004 & 71.15 & -101.33 & 472.38 \\
\hline 9 & 2005 & 100.40 & $14,865.16$ & $365,504.58$ \\
\hline 10 & 2006 & 102.50 & $19,008.51$ & $507,299.13$ \\
\hline 11 & 2007 & 71.50 & -80.17 & 345.71 \\
\hline 12 & 2008 & 220.00 & $2,997,694.38$ & $432,231,557.16$ \\
\hline 13 & 2009 & 83.00 & 371.38 & $2,669.51$ \\
\hline 14 & 2010 & 156.50 & $525,323.53$ & $42,387,304.85$ \\
\hline 15 & 2011 & 93.50 & $5,533.96$ & $97,884.72$ \\
\hline 16 & 2012 & 111.50 & $45,453.43$ & $1,622,141.89$ \\
\hline 17 & 2013 & 119.00 & $80,554.40$ & $3,478,983.51$ \\
\hline
\end{tabular}

Dengan hasil perhitungan pemilihan distribusi didapat distribusi Log Pearson dan distribusi Iwai yang memenuhi, dalam perhitungan tetap disertakan perhitungan dengan distribusi Gumbel sebagai pembanding. Berikut tabel perhitungan distribusi terpilih.

Tabel 7. Hujan Rancangan Metode Gumbel

\begin{tabular}{|c|c|c|c|}
\hline \multirow{2}{*}{ No } & $\mathbf{T}$ & $\mathbf{P}$ & $\mathbf{C H R}$ \\
\cline { 2 - 4 } & (tahun) & $\mathbf{( \% )}$ & (mm) \\
\hline 1 & 1.01 & 99 & 24.16 \\
\hline 2 & 1.25 & 80 & 69.09 \\
\hline 3 & 1.59 & 63 & 89.64 \\
\hline 4 & 1.67 & 60 & 93.12 \\
\hline 5 & 2 & 50 & 105.02 \\
\hline 6 & 2.5 & 40 & 118.04 \\
\hline 7 & 5 & 20 & 153.37 \\
\hline 8 & 10 & 10 & 185.37 \\
\hline 9 & 20 & 5 & 216.08 \\
\hline 10 & 25 & 4 & 225.81 \\
\hline 11 & 50 & 2 & 255.82 \\
\hline 12 & 100 & 1 & 285.60 \\
\hline 13 & 200 & 0.5 & 315.27 \\
\hline 14 & 500 & 0.2 & 354.41 \\
\hline 15 & 1000 & 0.1 & 384.00 \\
\hline
\end{tabular}

Tabel 8. Faktor Frekuensi Gumbel Type I

\begin{tabular}{|c|c|c|c|c|c|}
\hline \multirow{2}{*}{ No } & $\mathbf{T}$ & $\mathbf{P}$ & $\mathbf{( 1 - P )}$ & Reduced & \multicolumn{1}{|c|}{ K } \\
\cline { 2 - 4 } & (tahun) & $\mathbf{( \% )}$ & $\mathbf{( \% )}$ & & \\
\hline 1 & 1.01 & 99 & 0.010 & -1.53 & -1.97 \\
\hline 2 & 1.25 & 80 & 0.200 & -0.48 & -0.95 \\
\hline 3 & 1.59 & 63 & 0.370 & 0.01 & -0.49 \\
\hline 4 & 1.67 & 60 & 0.400 & 0.09 & -0.41 \\
\hline 5 & 2 & 50 & 0.500 & 0.37 & -0.15 \\
\hline 6 & 2.5 & 40 & 0.600 & 0.67 & 0.15 \\
\hline 7 & 5 & 20 & 0.800 & 1.50 & 0.94 \\
\hline 8 & 10 & 10 & 0.900 & 2.25 & 1.66 \\
\hline 9 & 20 & 5 & 0.950 & 2.97 & 2.36 \\
\hline 10 & 25 & 4 & 0.960 & 3.20 & 2.57 \\
\hline 11 & 50 & 2 & 0.980 & 3.90 & 3.25 \\
\hline 12 & 100 & 1 & 0.990 & 4.60 & 3.92 \\
\hline 13 & 200 & 0.5 & 0.995 & 5.30 & 4.59 \\
\hline 14 & 500 & 0.2 & 0.998 & 6.21 & 5.47 \\
\hline 15 & 1000 & 0.1 & 0.999 & 6.91 & 6.14 \\
\hline
\end{tabular}

Tabel 9. Analisa Hujan Rancangan Metode Gumbel

\begin{tabular}{|c|c|r|r|r|}
\hline No. & Tahun & \multicolumn{1}{|c|}{$\mathbf{X i}$} & \multicolumn{1}{|c|}{$(\mathbf{X i}-\mathbf{X})^{\mathbf{2}}$} & \multicolumn{1}{|c|}{$\left(\mathbf{X i} \mathbf{- X ) ^ { 3 }}\right.$} \\
\cline { 3 - 3 } & & $\mathbf{( m m )}$ & & \\
\hline 1 & 1997 & 60.25 & $2,625.36$ & $-134,518.65$ \\
\hline 2 & 2004 & 71.15 & $1,627.17$ & $-65,637.30$ \\
\hline 3 & 2007 & 71.50 & $1,599.06$ & $-63,943.55$ \\
\hline 4 & 2001 & 80.00 & 991.51 & $-31,220.87$ \\
\hline 5 & 2009 & 83.00 & 811.58 & $-23,120.47$ \\
\hline 6 & 2003 & 90.00 & 461.74 & $-9,922.07$ \\
\hline 7 & 2011 & 93.50 & 323.58 & $-5,820.57$ \\
\hline 8 & 2005 & 100.40 & 122.95 & $-1,363.29$ \\
\hline 9 & 1999 & 101.75 & 94.83 & -923.51 \\
\hline 10 & 2006 & 102.50 & 80.79 & -726.14 \\
\hline 11 & 2012 & 111.50 & 0.00 & 0.00 \\
\hline 12 & 1998 & 112.25 & 0.58 & 0.44 \\
\hline 13 & 2002 & 116.00 & 20.36 & 91.84 \\
\hline 14 & 2013 & 119.00 & 56.43 & 423.86 \\
\hline 15 & 2010 & 156.50 & $2,026.06$ & $91,196.49$ \\
\hline 16 & 2000 & 206.00 & $8,932.47$ & $844,223.85$ \\
\hline 17 & 2008 & 220.00 & $11,774.80$ & $1,277,704.66$ \\
\hline
\end{tabular}

Tabel 10. Hujan Rancangan Metode Log Pearson Type III

\begin{tabular}{|c|c|c|c|}
\hline \multirow{2}{*}{ No } & $\mathbf{T}$ & $\mathbf{P}$ & CHR \\
\cline { 2 - 4 } & (tahun) & (\%) & (mm) \\
\hline 1 & 1.01 & 99 & 56.49 \\
\hline 2 & 2 & 50 & 100.20 \\
\hline 3 & 5 & 20 & 137.90 \\
\hline 4 & 10 & 10 & 167.35 \\
\hline 5 & 20 & 5 & 194.80 \\
\hline 6 & 25 & 4 & 210.16 \\
\hline 7 & 50 & 2 & 246.38 \\
\hline 8 & 100 & 1 & 286.58 \\
\hline 9 & 200 & 0.5 & 331.68 \\
\hline 10 & 1000 & 0.1 & 457.31 \\
\hline
\end{tabular}

Tabel 11. Analisa Hujan Rancangan Metode Log Pearson Type III

\begin{tabular}{|c|c|c|c|c|c|c|}
\hline No. & Tahun & $\begin{array}{c}\mathrm{xi} \\
(\mathrm{mm})\end{array}$ & $\log X \mathrm{X}$ & $\log X_{i}-\log X$ & $(\log X i-\log X)^{2}$ & $(\log X i-\log X)^{3}$ \\
\hline 1 & 1997 & 60.25 & 1.78 & -0.24 & 0.058 & -0.013851 \\
\hline 2 & 2004 & 71.15 & 1.85 & -0.17 & 0.028 & -0.004736 \\
\hline 3 & 2007 & 71.50 & 1.85 & -0.17 & 0.027 & -0.004558 \\
\hline 4 & 2001 & 80.00 & 1.90 & -0.12 & 0.014 & -0.001603 \\
\hline 5 & 2009 & 83.00 & 1.92 & -0.10 & 0.010 & -0.001031 \\
\hline 6 & 2003 & 90.00 & 1.95 & -0.07 & 0.004 & -0.000286 \\
\hline 7 & 2011 & 93.50 & 1.97 & -0.05 & 0.002 & -0.000120 \\
\hline 8 & 2005 & 100.40 & 2.00 & -0.02 & 0.000 & -0.000006 \\
\hline 9 & 1999 & 101.75 & 2.01 & -0.01 & 0.000 & -0.000002 \\
\hline 10 & 2006 & 102.50 & 2.01 & -0.01 & 0.000 & -0.000001 \\
\hline 11 & 2012 & 111.50 & 2.05 & 0.03 & 0.001 & 0.000020 \\
\hline 12 & 1998 & 112.25 & 2.05 & 0.03 & 0.001 & 0.000027 \\
\hline 13 & 2002 & 116.00 & 2.06 & 0.04 & 0.002 & 0.000087 \\
\hline 14 & 2013 & 119.00 & 2.08 & 0.06 & 0.003 & 0.000170 \\
\hline 15 & 2010 & 156.50 & 2.19 & 0.17 & 0.030 & 0.005305 \\
\hline 16 & 2000 & 206.00 & 2.31 & 0.29 & 0.086 & 0.025348 \\
\hline 17 & 2008 & 220.00 & 2.34 & 0.32 & 0.104 & 0.033483 \\
\hline
\end{tabular}

Berdasarkan uraian tersebut maka nilai teraman ada pada Log Pearson. Sehingga untuk perhitungannya berikutnya menggunakan Hujan Rancangan Metode Log Pearson. 


\section{Karakter Tata Guna Lahan}

Penelusuran karakter Tata Guna Lahan pada Sub-sub DAS yang dianalisa meliputi jenis tata guna lahan dan koefisien pengaliran rata-rata pada sub catchment area. Tahapan dalam pengerjaan adalah menentukan jenis dan luas tata guna lahan, menghitung koefisien pengaliran pada setiap jenis tata guna lahan tersebut

\section{Menentukan Jenis dan Luas Tata Guna Lahan}

Pada tahun 1990-an, penggunaan lahan pada DAS D.I Sengkaling Kanan masih didominasi oleh lahan terbuka. Lahan terbuka diasumsikan pada jenis tata guna lahan sawah, lapangan, taman, tegalan dan tanah kosong. Kondisi ini dari tahun ke tahun mengalami penurunan karena pertumbuhan penduduk yang mengakibatkan berubahnya fungsi lahan terbuka menjadi daerah pemukiman dan segala fasilitas pendukungnya. Perubahan fungsi ini sebagian besar disebabkan area ini merupakan area kampus yang dari tahun ke tahun mengalami kenaikan penerimaan mahasiswa baru, sehingga banyak area terbuka yang beralih fungsi menjadi area hunian, baik perumahan maupun kos-kosan. Tabel tata guna lahan dibagi menjadi 3 Sub DAS D.I Sengkaling Kanan berdasarkan rencana penempatan pelimpah samping pada wilayah studi.

Tabel 12. Tata Guna Lahan DAS D.I. Sengkaling Kanan

\begin{tabular}{|c|c|c|c|c|}
\hline \multirow[t]{2}{*}{ No } & \multirow[t]{2}{*}{ Nama Sub DAS } & \multirow[t]{2}{*}{ Jenis Tata Guna Lahan } & Luas Area & Persen Area \\
\hline & & & (m2) & (\%) \\
\hline \multirow[t]{3}{*}{1} & DTA 1 & Sawah dan tegalan & $32,400.14$ & $9.23 \%$ \\
\hline & & Perumahan dan perkantoran & $318,756.29$ & $90.77 \%$ \\
\hline & & Jumlah & $351,156.44$ & $100.00 \%$ \\
\hline \multirow[t]{3}{*}{2} & DTA 2 & Sawah dan tegalan & $169,292.94$ & $10.24 \%$ \\
\hline & & Perumahan dan perkantoran & $1,484,435.59$ & $89.76 \%$ \\
\hline & & Jumlah & $1,653,728.53$ & $100.00 \%$ \\
\hline & & & & \\
\hline \multirow[t]{3}{*}{3} & DTA Outlet & Sawah dan tegalan & 0.00 & $0.00 \%$ \\
\hline & & Perumahan dan perkantoran & $465,739.50$ & $100.00 \%$ \\
\hline & & Jumlah & $465,739.50$ & $100.00 \%$ \\
\hline & & & & \\
\hline & & & & \\
\hline
\end{tabular}

Seiring dengan dibangunnya fasilitas tersebut, pertumbuhan fasilitas lainnya juga semakin pesat, diantaranya pembangunan pertokoan, dan pemukiman penduduk. Hal tersebut mengakibatkan berubahnya fungsi kawasan terbuka menjadi kawasan terbangun yang diasumsikan pada jenis tata guna lahan permukiman, perdagangan dan jasa, pendidikan, dan jalan aspal. Berikut adalah gambar kondisi tata guna lahan area DTA D.I Sengkaling Kanan pada Tahun 2015, gambar tersebut didapat dari Peta Google Earth.

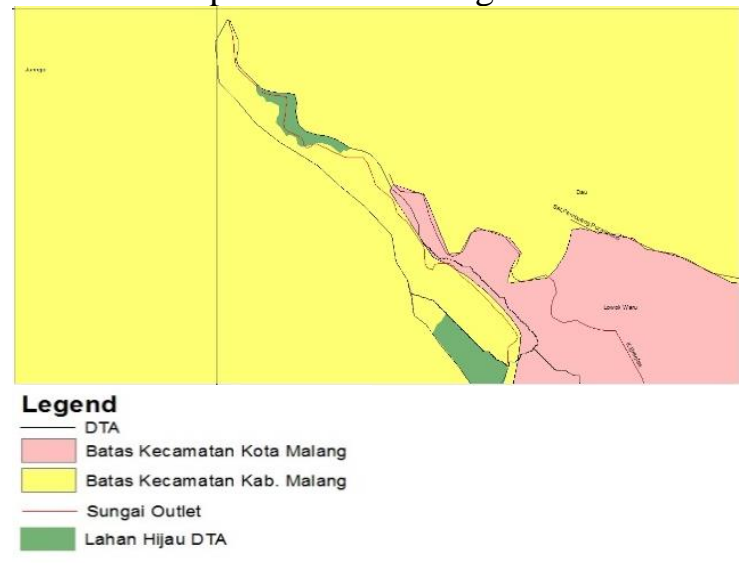

\section{Gambar 5. Peta Tata Guna Lahan DTA} Pelimpah 1

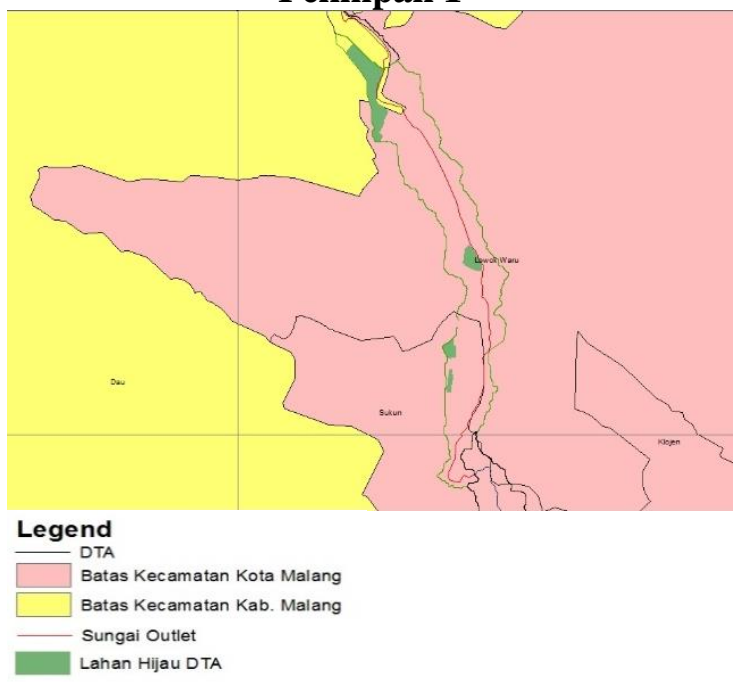

\section{Gambar 6. Peta Tata Guna Lahan DTA Pelimpah 2}

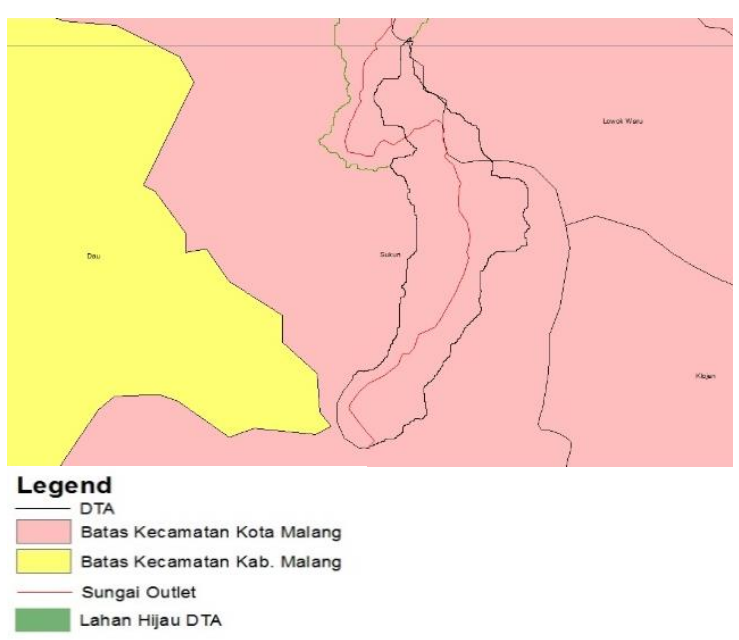

Gambar 7. Peta Tata Guna Lahan DTA Outlet 


\section{Evaluasi Kondisi Saluran Eksisting terhadap Genangan}

Genangan yang terjadi diakibatkan kapasitas saluran tidak mampu lagi menampung debit limpasan permukaan yang terjadi. Hal ini terjadi karena bercampurnya saluran irigasi dan saluran drainase.

Berikut gambar skema yang menunjukkan kondisi debit di masing-masing bagian Sub DAS D.I Sengkaling Kanan

\begin{tabular}{|c|c|c|c|c|}
\hline & \multicolumn{2}{|c|}{ Q Kumulatif } & \multirow[t]{2}{*}{ Q Inflow } & \multirow[b]{3}{*}{ (m3/dt) } \\
\hline & & Inlet & & \\
\hline \multirow[t]{2}{*}{6.84} & (m3/dt) & & 6.84 & \\
\hline & & Sub DAS 1 & & \\
\hline \multirow[t]{2}{*}{7.83} & $(\mathrm{~m} 3 / \mathrm{dt})$ & & 0.99 & $(\mathrm{~m} 3 / \mathrm{dt})$ \\
\hline & & Sub DAS 2 & & \\
\hline \multirow[t]{3}{*}{8.34} & (m3/dt) & & 0.51 & $(\mathrm{~m} 3 / \mathrm{dt})$ \\
\hline & & & & \\
\hline & & Sub DAS 3 & & \\
\hline \multirow[t]{2}{*}{10.47} & $(\mathrm{~m} 3 / \mathrm{dt})$ & & 2.13 & (m3/dt) \\
\hline & & Sub DAS 4 & & \\
\hline \multirow[t]{3}{*}{12.05} & (m3/dt) & & 1.58 & (m3/dt) \\
\hline & & & & \\
\hline & & Sub DAS 5 & & \\
\hline \multirow[t]{2}{*}{13.04} & $(\mathrm{~m} 3 / \mathrm{dt})$ & & 0.99 & (m3/dt) \\
\hline & & Sub DAS 6 & & \\
\hline \multirow[t]{2}{*}{13.63} & (m3/dt) & & 0.59 & (m3/dt) \\
\hline & & Sub DAS 7 & & \\
\hline \multirow[t]{3}{*}{14.70} & (m3/dt) & & 1.07 & (m3/dt) \\
\hline & & SuhDAS 8 & & \\
\hline & & & & \\
\hline \multirow[t]{2}{*}{15.58} & (m3/dt) & & 0.88 & (m3/dt) \\
\hline & & Sub DAS 9 & & \\
\hline \multirow[t]{3}{*}{16.85} & $(\mathrm{~m} 3 / \mathrm{dt})$ & & 1.27 & $(\mathrm{~m} 3 / \mathrm{dt})$ \\
\hline & & & & \\
\hline & & Sub DAS 10 & & \\
\hline \multirow[t]{3}{*}{17.73} & $(\mathrm{~m} 3 / \mathrm{dt})$ & & 0.88 & (m3/dt) \\
\hline & & & & \\
\hline & & Outlet & & \\
\hline
\end{tabular}

\section{Gambar 8. Skema Q Limpasan terhadap Q kumulatif}

Evaluasi kapasitas saluran irigasi eksisting bertujuan untuk mengetahui kemampuan saluran dalam menampung debit limpasan lahan yang terjadi. Kapasitas saluran irigasi eksisting ini untuk selanjutnya dibandingkan dengan kapasitas saluran seharusnya.

Berikut gambar skema yang menunjukkan perbandingan antara kapasitas saluran eksisting dengan debit limpasan lahan kumulatif.

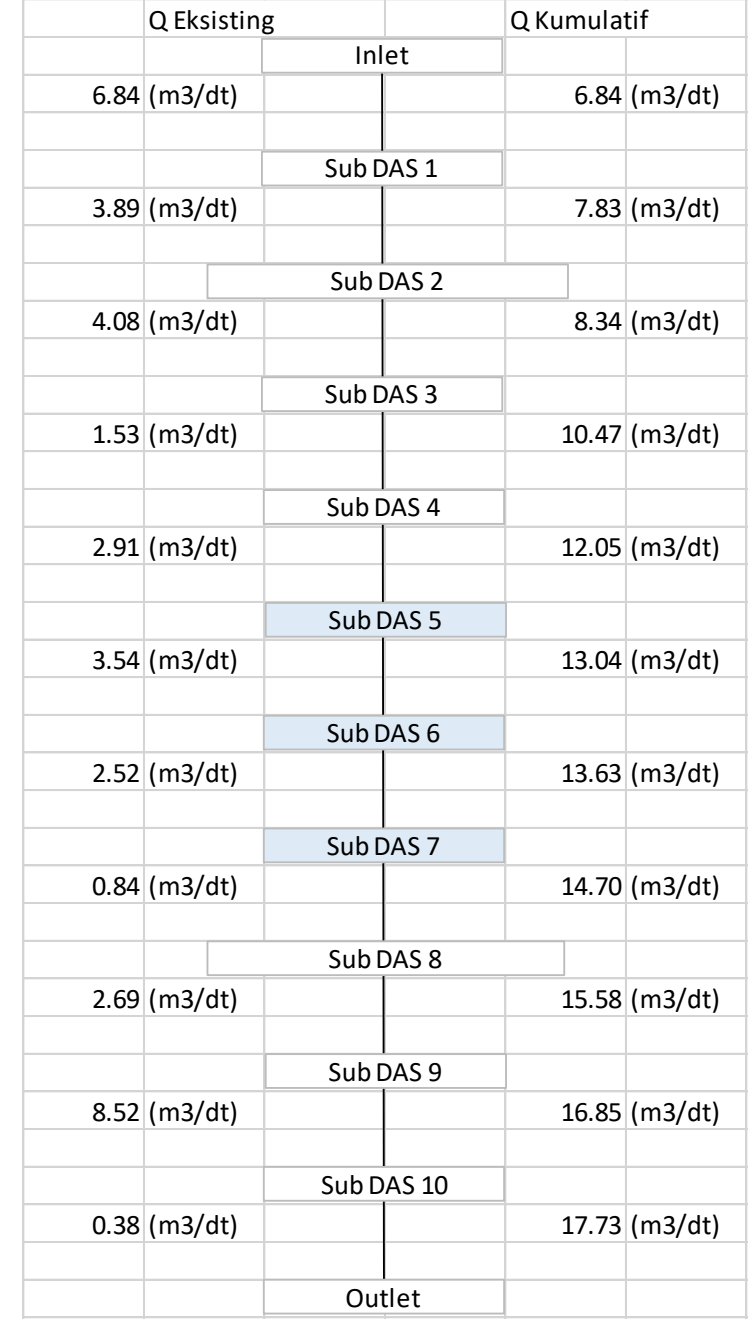

\section{Gambar 9. Skema Q Limpasan Kumulatif terhadap Kapasitas Saluran Eksisting}

\section{Perencanaan Pelimpah Samping}

Pelimpah samping pada studi ini dimaksudkan sebagai pengurang $\mathrm{Q}$ banjir yang ditampung pada saluran irigasi eksisting, jumlah pelimpah samping dan jumlah debit yang akan dilewatkan, direncanakan sesuai dengan kondisi pada daerah studi. Pada studi kasus ini akan direncanakan 2 pelimpah samping. Pelimpah samping yang pertama akan diletakkan di section 2 sebagai pencegah banjir pada section 5,6, dan 7 dan pelimpah samping yang kedua akan diletakkan pada section 8 sebagai pencegah banjir pada section 9 dan 10. Sedangkan debit banjir yang akan dilewatkan pada pelimpah samping 1 adalah $5,45 \mathrm{~m}^{3} / \mathrm{dt}$ mengurangi debit dengan jumlah $10,453 \mathrm{~m}^{3} / \mathrm{dt}$, dan pada pelimpah 2 adalah 5,52 $\mathrm{m}^{3} / \mathrm{dt}$ mengurangi debit dengan jumlah 10,52 $\mathrm{m}^{3} / \mathrm{dt}$. 
Data-data perencanaan pelimpah samping :

- Q2th Kumulatif $=10,45 \mathrm{~m}^{3} / \mathrm{dt}$

- Q yang dilewatkan $=5,00 \mathrm{~m}^{3} / \mathrm{dt}$

- Q Pelimpah Samping $=5,45 \mathrm{~m}^{3} / \mathrm{dt}$

- Q0 $=5,45 \mathrm{~m}^{3} / \mathrm{dt}$

- Tinggi muka air hilir (ho) $=1 \mathrm{~m}$

- Kecepatan Aliran (Vo) $=0,72$

- Tinggi Energi $=\mathrm{ho}+\mathrm{Vo}^{2} / 2 \mathrm{~g}=1,03$

- C (tinggi dasar pelimpah terhadap dasar saluran $)=0,5$ (direncanakan)

- $\mu$ $=0,38$

- $\mathrm{h}$ (tinggi muka air saluran) $=1 \mathrm{~m}$

- $\mathrm{b}$ (lebar saluran) $\quad=5 \mathrm{~m}$

Berikut perhitungan pelimpah samping 1

Tabel 13. Perhitungan Pelimpah Samping 1

\begin{tabular}{|c|c|c|c|c|c|c|c|c|c|c|}
\hline$\Delta x$ & Qo & Ho & ho & ho-c & qx & Qo+qx & Ax & vx & hx & $\Delta x$ \\
\hline 1 & 5.45 & 1.03 & 0.716 & 0.216 & 0.161 & 5.614 & 4.093 & 1.372 & 0.930 & 1.00 \\
\hline 2 & 5.61 & 1.03 & 0.930 & 0.430 & 0.902 & 6.516 & 5.516 & 1.181 & 0.955 & 3.00 \\
\hline 2 & 6.52 & 1.03 & 0.955 & 0.455 & 0.981 & 7.497 & 5.687 & 1.318 & 0.937 & 5.00 \\
\hline 2 & 7.50 & 1.03 & 0.937 & 0.437 & 0.925 & 8.422 & 5.566 & 1.513 & 0.909 & 7.00 \\
\hline 2 & 8.42 & 1.03 & 0.909 & 0.409 & 0.837 & 9.260 & 5.373 & 1.723 & 0.875 & 9.00 \\
\hline 2 & 9.26 & 1.03 & 0.875 & 0.375 & 0.733 & 9.993 & 5.138 & 1.945 & 0.833 & 11.00 \\
\hline 2 & 9.99 & 1.03 & 0.833 & 0.333 & 0.615 & 10.608 & 4.860 & 2.183 & 0.783 & 13.00 \\
\hline \multicolumn{70}{|c|}{$\Sigma=$} & 5.155 \\
\hline
\end{tabular}

Didapat dengan lebar pelimpah $13 \mathrm{~m}$ dapat mengalirkan debit sebesar $5,155 \mathrm{~m}^{3} / \mathrm{dt}$

Sehingga skema kumulatif pada section setelah pelimpah 1 menjadi

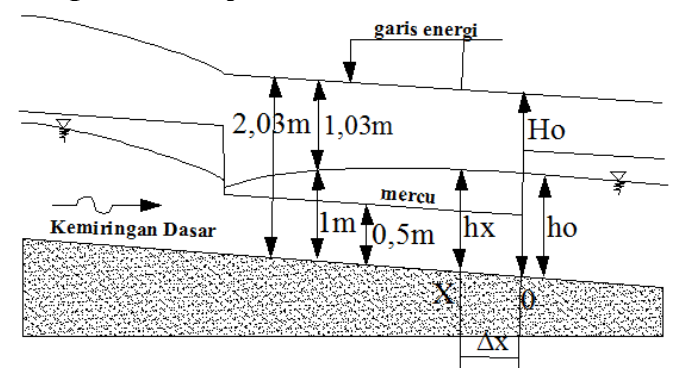

Gambar 10. Sketsa Potongan Memanjang Bangunan Pelimpah Samping 1

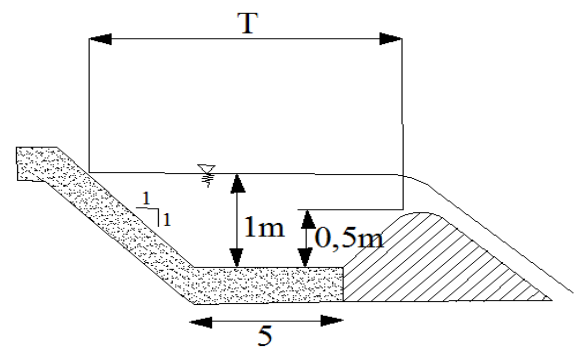

Gambar 11. Sketsa Potongan Melebar Bangunan Pelimpah Samping 1

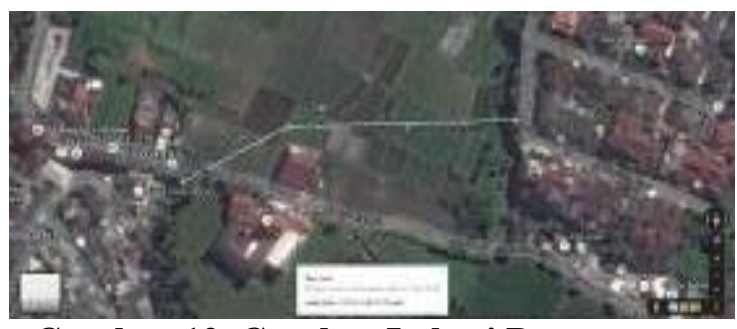

\section{Gambar 12. Gambar Lokasi Penempatan} Saluran ke Arah Sungai Pembuang

Berdasarkan gambar diatas diketahui jarak antara pelimpah 1 dan sungai pembuang adalah 172,14 $\mathrm{m}$ dengan panjang saluran pembawa $176,2 \mathrm{~m}$ dan lebar lebar pelimpah samping $1 \pm 13 \mathrm{~m}$

Data-data perencanaan pelimpah samping 2:

- Q2th Kumulatif $\quad=10,52 \mathrm{~m}^{3} / \mathrm{dt}$

- Q yang dilewatkan $\quad=5,00 \mathrm{~m}^{3} / \mathrm{dt}$

- Q Pelimpah Samping $\quad=5,52 \mathrm{~m}^{3} / \mathrm{dt}$

- $\mathrm{Q} 0=5,52 \mathrm{~m}^{3} / \mathrm{dt}$

- Tinggi muka air hilir (ho) $=1 \mathrm{~m}$

- $\operatorname{Kecepatan}$ Aliran (Vo) $=0,56$

- Tinggi Energi $=\mathrm{ho}+\mathrm{Vo}^{2} / 2 \mathrm{~g}=1,02$

- C (tinggi dasar pelimpah terhadap dasar saluran $)=0,5$ (direncanakan)

- $\mu \quad=0,38$

- $\mathrm{h}$ (tinggi muka air saluran) $=2 \mathrm{~m}$

- $\mathrm{b}$ (lebar saluran) $\quad=4 \mathrm{~m}$

Berikut perhitungan pelimpah samping 2

Tabel 14. Perhitungan Pelimpah Samping 2

\begin{tabular}{|c|c|c|c|c|c|c|c|c|c|c|}
\hline$\Delta \mathrm{x}$ & Qo & Ho & ho & ho-c & $\mathrm{qx}$ & $\mathrm{Q} 0+\mathrm{qx}$ & $\mathrm{Ax}$ & $\mathrm{vx}$ & $\mathrm{hx}$ & $\Delta \mathrm{x}$ \\
\hline 1 & 5.52 & 1.02 & 0.558 & 0.058 & 0.022 & 5.542 & 2.853 & 1.942 & 0.828 & 1.00 \\
\hline 2 & 5.54 & 1.02 & 0.828 & 0.328 & 0.599 & 6.142 & 4.680 & 1.312 & 0.932 & 3.00 \\
\hline 2 & 6.14 & 1.02 & 0.932 & 0.432 & 0.908 & 7.050 & 5.466 & 1.290 & 0.935 & 5.00 \\
\hline 2 & 7.05 & 1.02 & 0.935 & 0.435 & 0.918 & 7.968 & 5.489 & 1.452 & 0.913 & 7.00 \\
\hline 2 & 7.97 & 1.02 & 0.913 & 0.413 & 0.847 & 8.815 & 5.315 & 1.658 & 0.880 & 9.00 \\
\hline 2 & 8.82 & 1.02 & 0.880 & 0.380 & 0.748 & 9.563 & 5.066 & 1.888 & 0.838 & 11.00 \\
\hline 2 & 9.56 & 1.02 & 0.838 & 0.338 & 0.629 & 10.192 & 4.758 & 2.142 & 0.786 & 13.00 \\
\hline 2 & 10.19 & 1.02 & 0.786 & 0.286 & 0.489 & 10.681 & 4.379 & 2.439 & 0.716 & 15.00 \\
\hline \multicolumn{7}{|c|}{$\Sigma=$} & 5.161 & \\
\hline
\end{tabular}

Didapat dengan lebar pelimpah $15 \mathrm{~m}$ dapat mengalirkan debit sebesar $5,161 \mathrm{~m}^{3} / \mathrm{dt}$

Berikut gambar sketsa bangunan pelimpah samping 2 


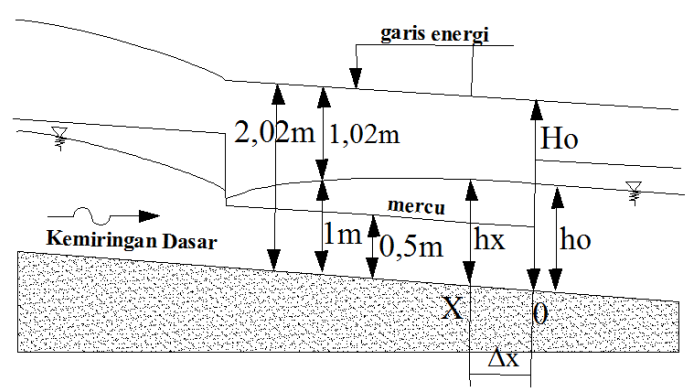

Gambar 13. Sketsa Potongan Memanjang Bangunan Pelimpah Samping 2

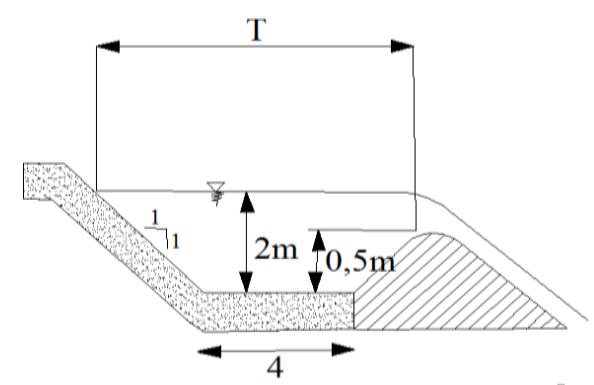

Gambar 14. Sketsa Potongan Melebar Bangunan Pelimpah Samping 2

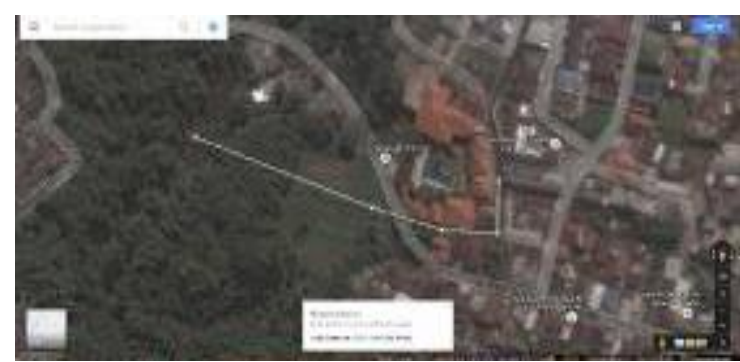

Gambar 15. Gambar Lokasi Penempatan Saluran ke Arah Sungai Pembuang

Berdasarkan gambar diatas diketahui jarak antara pelimpah 2 dan sungai pembuang adalah 215,17 $\mathrm{m}$ dengan panjang saluran pembawa $215,17 \mathrm{~m}$ dan lebar lebar pelimpah samping $2 \pm 15 \mathrm{~m}$.

Berikut tabel perbandingan $Q$ kumulatif sebelum dan setelah dipasang pelimpah terhadap Q eksisting

Tabel 15. Tabel Perbandingan Q kumulatif terhadap $\mathrm{Q}$ eksisting dengan dan tanpa Pelimpah

\begin{tabular}{|c|c|c|c|c|}
\hline \multirow{2}{*}{ Sub DAS } & Q Eksisiting & Tanpa Pelimpah & Dengan Pelimpah 1 & Dengan pelimpah 1\&2 \\
\cline { 2 - 5 } & $\mathrm{m}^{3} / \mathrm{dt}$ & $\mathrm{m}^{3} / \mathrm{dt}$ & $\mathrm{m}^{3} / \mathrm{dt}$ & $\mathrm{m}^{3} / \mathrm{dt}$ \\
\hline Inlet & 6.84 & 6.84 & 6.84 & 6.84 \\
\hline 1 & 3.89 & 7.83 & 7.83 & 7.83 \\
\hline 2 & 4.08 & 8.34 & 8.34 & 8.34 \\
\hline 3 & 1.53 & 10.47 & 5.47 & 5.47 \\
\hline 4 & 2.91 & 12.05 & 7.05 & 7.05 \\
\hline 5 & 3.54 & 13.04 & 8.04 & 8.04 \\
\hline 6 & 2.52 & 13.63 & 8.63 & 8.63 \\
\hline 7 & 0.84 & 14.70 & 9.70 & 9.70 \\
\hline 8 & 2.69 & 15.58 & 10.58 & 5.58 \\
\hline 9 & 8.52 & 16.85 & 11.85 & 6.85 \\
\hline 10 & 0.38 & 17.73 & 12.73 & 7.73 \\
\hline
\end{tabular}

\section{KESIMPULAN DAN SARAN}

\section{Kesimpulan}

Berdasarkan hasil analisa pada bab-bab sebelumnya maka kesimpulan dalam penelitian adalah sebagai berikut:

1. Dari hasil perhitungan perencanaan pelimpah samping didapat hasil perhitungan rencana pelimpah samping 1 dengan lebar $13 \mathrm{~m}$ dapat mengalirkan debit sejumlah $5,155 \mathrm{~m}^{3} / \mathrm{dt}$ dari debit rencana $5,47 \mathrm{~m}^{3} / \mathrm{dt}$ dan pelimpah samping 2 dengan lebar $15 \mathrm{~m}$ mengalirkan debit sejumlah $5,161 \mathrm{~m}^{3} / \mathrm{dt}$ dari debit rencana $5,58 \mathrm{~m}^{3} / \mathrm{dt}$.

\section{Saran}

Berdasarkan analisa pada kajian ini, maka disarankan beberapa hal sebagai berikut:

1. Hasil penelitian ini diharapkan dapat menjadi dasar dalam pengambilan keputusan untuk pengelolaan DTA D.I Sengkaling Kanan selanjutnya, agar dapat meningkatkan kualitas kinerja daerah irigasi tersebut.

2. Pada DTA D.I Sengkaling Kanan diperlukan adanya penangan tambahan untuk menanggulangi permasalahan perubahan fungsi lahan dengan baik, dengan begitu maka kualitas kinerja DTA D.I Sengkaling Kanan akan semakin baik, yang akan berdampak pada kualitas manusia yang berada di lingkungan tersebut.

3. Adanya sangsi tegas dalam pelanggaran rencana tata ruang wilayah juga diperlukan. Apabila regulasi sudah tidak dapat diandalkan maka penanganan secara teknik harus diperlukan

4. Untuk pengembangan penelitian selanjutnya diharapkan adanya survey saluran irigasi eksisting dengan lebih akurat dan perhitungan luas lahan persawahan yang masih membutuhkan debit irigasi dengan baik.

\section{DAFTAR PUSTAKA}

Asdak, Chay. 2002. Hidrologi dan Pengelolaan Daerah Aliran Sungai, Gajah Mada University Press, Yogyakarta.

Prahasta, Eddy. 2005. Sistem Informasi Geografis : Tutorial Arcview. Informatika. Bandung. 
Suhardjono, 2015. Drainase Perkotaan. Fakultas Teknik Universitas Brawijaya, Malang
Sunjoto. 1991. Hidrolika Sumur Resapan. Pusat Antar Universitas Ilmu Teknik Universitas Gadjah Mada, Yogyakarta. Triadmodjo, Bambang. 2010. Hidrologi Terapan. Beta Offset, Yogyakarta. 